International Journal of Medical Sciences

ISSN 1449-1907 www.medsci.org 2008 5(4):209-217

Review

(C) Ivyspring International Publisher. All rights reserved

\title{
Molecular Predictors of EGFR-TKI Sensitivity in Advanced Non-small Cell Lung Cancer
}

\author{
Xiaozhu Zhang, Alex Chang \\ International Medical Centre, Johns Hopkins Singapore, Singapore
}

Correspondence to: Zhang Xiaozhu, Johns Hopkins Singapore International Medical Centre, 11 Jalan Tan Tock Seng, Singapore 308433. Tel: 65-63266115; Fax: 65-62273787; Email: xiaozhu@imc.jhmi.edu

Received: 2008.05.22; Accepted: 2008.07.10; Published: 2008.07.11

The epidermal growth factor receptor (EGFR) is overexpressed in the majority of non-small cell lung cancers (NSCLC) and is a major target for new therapies. Specific EGFR tyrosine kinase inhibitors (TKIs) have been developed and used for the treatment of advanced NSCLC. The clinical response, however, varies dramatically among different patient cohorts. Females, East Asians, non-smokers, and patients with adenocarcinoma usually show higher response rates. Meanwhile, a number of biological factors are also associated with EGFR-TKIs responsiveness. In order to better understand the predictive value of these biomarkers and their significance in clinical application we prepared this brief review. Here we mainly focused on EGFR somatic mutations, MET amplification, K-ras mutations, EGFRvIII mutation, EGFR gene dosage and expression, HER2 gene dosage and expression, and Akt phosphorylation. We think EGFR somatic mutation probably is the most effective molecular predictor for EGFR-TKIs responsiveness and efficacy. Mutation screening test can provide the most direct and valuable guidance for clinicians to make decision on EGFR-TKIs therapy.

Key words: non-small cell lung cancer, EGFR, somatic mutation, tyrosine kinase inhibitor, gene amplification

\section{Introduction}

Lung cancer is one of the most common human cancers and the leading cause of cancer death worldwide (1). Lung cancer is generally classified into two histological types, small cell lung cancer (SCLC) and non-small cell lung cancer (NSCLC). NSCLC accounts for approximately $85 \%$ of the cases and it is further divided into squamous-cell carcinoma (SSC), adenocarcinoma (AC), large cell carcinoma, and others (2). Adenocarcinoma has become the most prevalent subtype of NSCLC in recent decades $(3,4)$. The treatment of lung cancer is mainly based on the stage of cancer, patients' performance status, comorbidity, etc (5). For patients with early stage disease (stage I or II) surgical resection is considered the primary therapeutic choice. It is worth taking notice, however, that majority of NSCLC cases have reached locally advanced (stage III) or metastatic stage (stage IV) at the time of diagnosis (6), and chemotherapy is usually recommended as the first line therapy.

Chemotherapy is often considered too toxic, particularly for elderly patients and patients with poor performance status. The well-established platinum-based regimen can only bring modest survival benefit by increasing the median survival time about three months in average $(7,8)$. In recent years more effort has been put onto the development of molecular-targeted drugs.

Epidermal growth factor receptor (EGFR) is overexpressed in the majority of NSCLC and it is an important target in the treatment of NSCLC. EGFR is a member of the family of EGF-related tyrosine kinase receptors. Upon ligands binding, the receptors homoor hetero-dimerize. Subsequently, it activates receptors' intrinsic tyrosine kinase activity and broad downstream signaling cascades, mainly including Ras-Raf-MAP-kinase pathway, PI3K-Akt pathway, and STAT pathway. All these have strong stimulatory effect on cell proliferation, differentiation, survival, angiogenesis and migration (9-11). EGFR has emerged as a critical tumorigenic factor in the development and progression of NSCLC (12-14). Two specific EGFR tyrosine kinase inhibitors (TKIs), gefitinib (ZD1839, Iressa) and erlotinib (OSI-774, Tarceva), have been developed and used clinically in the treatment of advanced NSCLC. These two drugs disrupt EGFR signaling by competing with adenosine triphosphate (ATP) for the binding sites at tyrosine kinase domain, 
and thus inhibiting the phosphorylation and activation of EGFRs and the downstream signaling network. Both agents can induce dramatic clinical response in patients who fail chemotherapy. Erlotinib and gefitinib have been shown to have survival benefit in Caucasians and Asians respectively when compared to placebo in controlled double-blinded randomized phase III trials $(15,16)$. However, among unselected NSCLC patients the objective response rate is only about $10 \%(17,18)$. Female patients, nonsmokers, East Asians, and patients with lung adenocarcinoma are noted to have higher response rates (17-19). In addition, many laboratories have found a number of other factors which are associated with EGFR-TKIs sensitivity. In order to better understand and interpret these basic and clinical research knowledge and accelerate the translation of research findings into daily medical practice, we reviewed the literature and carefully evaluated the predictive value of these biomarkers. We hope this brief review could provide useful information for clinicians, patients, and research professionals, help clinicians to select the right subgroup of NSCLC patients for EGFR-TKI therapy with high frequency of success, and to stimulate future research interest and effort in targeted therapy for NSCLC patients.

\section{Somatic mutations in EGFR}

Somatic mutation is the mutation that occurs only in somatic cells, which are in contrast to germ cells. A number of somatic mutations have been identified in the EGFR gene in NSCLC. In general these mutations can be classified into three major types: in-frame deletion, insertion, and mis-sense mutation. Most of the mutations are located in the tyrosine kinase coding domain (exons 18-21) of the EGFR gene. The amino acids 746 753 encoded by exon 19 and amino acid 858 encoded by exon 21 are two mutation hotspots, which accounts for over $80 \%$ of all the detected mutations.

\section{Gefitinib sensitive mutations}

A number of retrospective studies have reported that two activating mutations, small in-frame deletion in exon 19 (746 753) and substitution of leucine for arginine at amino acid 858 in exon 21 (L858R), have striking correlation with EGFR-TKI sensitivity (20-28). This discovery has been claimed as the most significant molecular event in lung cancer (29). Both activating mutations are able to enhance kinase activity of EGFR and the activation of its downstream signaling, and play a pivotal role in supporting NSCLC cell survival $(20,30)$. When specific EGFR-TKIs are applied, the excessive survival signals that cancer cells are "addicted to" are counteracted and dramatic apoptosis occurs $(30,31)$.

Seven phase II prospective studies (32-38) performed with gefitinib or erlotinib in EGFR mutation positive NSCLC patients have also demonstrated over $87 \%$ of response and disease control rate, and the duration of progression free survival ranges from 7.7 to 14 months, which is much longer than those reported in the literature by chemotherapy or other targeted therapy in unselected patient population (usually $4 \sim 6$ months). In addition, the response rates were quite similar regardless race, gender, histology, or smoking history (Table 1). Some of the studies have suggested better quality of life and longer survival occurred in patients treated with gefitinib or erlotinib $(26,27,39)$. All these demonstrate that EGFR activating mutations are effective predictor for EGFR-TKIs responsiveness and prognosis. Prospective randomized studies, however, are still needed to compare EGFR-TKIs with chemotherapy in NSLCLC patients with positive EGFR mutation to establish the role of EGFR-TKIs as the treatment choice in such patients.

Table 1 Prospective studies of gefitinib/erlotinib in EGFR mutation positive NSCLC patients

\begin{tabular}{|c|c|c|c|c|c|c|c|c|}
\hline Author & $\begin{array}{l}\text { No. of par- } \\
\text { ticipating } \\
\text { patients with } \\
\text { EGFR muta- } \\
\text { tions }\end{array}$ & Ethnicity & $\begin{array}{l}\text { EGFR mutation screening } \\
\text { method }\end{array}$ & $\begin{array}{l}\text { Overall } \\
\text { response } \\
\text { and disease } \\
\text { control rate }\end{array}$ & $\begin{array}{l}\text { Complete } \\
\text { response } \\
(\%)\end{array}$ & $\begin{array}{l}\text { Partial } \\
\text { response } \\
(\%)\end{array}$ & $\begin{array}{l}\text { Stable } \\
\text { disease } \\
(\%)\end{array}$ & $\begin{array}{l}\text { Median } \\
\text { progres- } \\
\text { sion-free } \\
\text { survival } \\
\text { (Months) }\end{array}$ \\
\hline $\begin{array}{l}\text { Yoshida K et al } \\
\text { (35) }\end{array}$ & 21 & Japanese & $\begin{array}{l}\text { Gene scan \& cycleave real-time } \\
\text { quantitative PCR technology }\end{array}$ & $91 \%$ & $3(14 \%)$ & $16(76 \%)$ & 0 & 7.7 \\
\hline Sunaga N, et al (32) & 21 & Japanese & Sequencing & $91 \%$ & $3(14 \%)$ & $13(62 \%)$ & $3(14 \%)$ & 12.9 \\
\hline Inoue $\mathrm{A}$, et al (34) & 16 & Japanese & Sequencing & $88 \%$ & 0 & $12(75 \%)$ & $2(13 \%)$ & 9.7 \\
\hline Asahina H, et al (33) & 16 & Japanese & Sequencing & $81 \%$ & $2(13 \%)$ & $10(62 \%)$ & $1(6 \%)$ & 8.9 \\
\hline Paz-Ares L, et al (36) & 21 & Caucasian & Gene scan \& TaqMan assay & $91 \%$ & $6(29 \%)$ & $13(62 \%)$ & 0 & $>8$ \\
\hline $\begin{array}{l}\text { van Zandwijk N, et } \\
\text { al (37) }\end{array}$ & 13 & Caucasian & Sequencing and gene scan & $92 \%$ & $1(8 \%)$ & $10(77 \%)$ & $1(8 \%)$ & 14 \\
\hline Sequist LV, et al (38) & 31 & $\begin{array}{l}\text { Asian \& } \\
\text { others }\end{array}$ & Sequencing & $94 \%$ & $1(3 \%)$ & $16(52 \%)$ & $12(39 \%)$ & 9.2 \\
\hline
\end{tabular}


Deletion in exon 19 and L858R are usually more common in women, East Asians, light smokers (less than 15 pack-years), and patients with adenocarcinoma (reviewed in (40)). Some studies have reported that exon 19 deletion is superior to L858R in prediction of response rates and survival $(26,39,41)$. However, conflict results indicate there is no significant difference observed between these two mutations (33, $34)$. More studies are required to clarify this issue.

\section{EGFR-TKIs resistant mutaions}

T790M, D761Y, L747S, and insertion in exon 20 are associated with resistance to EGFR-TKIs (42-47). T790 is located at the key position in ATP binding cleft of EGFR and is considered the gatekeeper residue. The introduction of T790M mutation increases ATP affinity of receptors, which relatively attenuates the binding of EGFR-TKIs (48). T790M is mainly present in relapsed tumors after an initial response and secondary to EGFR-TKIs therapy $(42,43)$, and it accounts for about half of acquired resistance to gefitinib or elotinib (44). Therefore, T790M has been considered a specific marker for acquired resistance to EGFR-TKIs. L747S, D761Y and insertions in exon 20 also confer modest resistance to EGFR-TKIs. However, they are not as common as T790M among NSCLC patients with acquired resistance to EGFR-TKIs.

\section{2. $M E T$ amplification}

MET is a high affinity tyrosine kinase receptor for hepatocyte growth factor (HGF)/ scatter factor. The binding of HGF results in autophosphorylation of MET at multiple tyrosine residues and activation of many downstream signaling components, which produce profound effect on cellular motility, growth, survival, invasion, and metastasis (49). Alteration of MET pathway contributes to the development and progression of a number of human tumors. Amplification of the MET gene has been detected in gastric cancers $(10 \sim 20 \%)$ and esophageal cancers $(50,51)$. In addition, activating mutations of MET are observed in papillary renal carcinoma (52). MET amplification has been observed in NSCLC and it is associated with EGFR-TKI resistance $(53,54)$. Its incidence is about $21 \%$ (9 out of 43 ) among patients with acquired resistance. Among untreated patients it occurs much less frequently (about 3\%) (53). MET amplification is able to activate ERBB3 (HER3)-dependent PI3K/Akt pathway, and ultimately lead to gefitinib resistance (54). Its occurrence is independent of T790M (53).

\section{K-ras mutation}

Ras is one of the important molecules in the downstream of EGFR signaling pathway. Ras is able to activate serine/theronine kinase Raf, the mito- gen-activated protein kinases ERK1 and ERK2, and a number of nuclear proteins to promote cell proliferation. Ras genes, especially $K$-ras, have been implicated in the pathogenesis and prognosis of lung cancer (55). Mutated K-ras can been observed among 20 30\% NSCLC patients. Majority of the mutations (approximately $80 \sim 90 \%$ ) are guanine to thymine transversion in codon 12, which results in constitutive activation of K-ras protein $(56,57)$. NSCLC patients with K-ras mutations are associated with unfavorable prognosis (58-60).

The correlation of K-ras mutations with EGFR mutations and gefitinib response has been investigated by several groups (61-63). In general, the mutations of EGFR and K-ras are mutually exclusive. NSCLC patients with $K$-ras mutations have poor sensitivity to EGFR-TKIs $(25,64)$. Screening K-ras mutation among NSCLC patients who are negative for EGFR mutations could provide additional information to avoid EGFR-TKIs.

\section{Type III epidermal growth factor receptor mu- tation}

Type III deletion mutation (EGFRvIII) is the deletion of exons 2 7, a 801bp fragment of EGFR cDNA, which produces a truncated receptor lacking a portion of extracellular ligand binding domain (65). The truncated receptor, however, is oncogenic. It has constitutive kinase activity, which is strong enough to activate downstream signaling cascades and gives cells growth advantage $(66,67)$. EGFRvIII has been identified in a number of human solid tumors, including glioblastoma, breast cancer, ovarian cancer, prostate cancer, and lung caner (66-69). The incidence of EGFRvIII in NSCLC varies among studies. Okamoto et al and Garcdia et al have identified 16\% (5 of 32) and 39\% (30 of 76) of EGFRvIII using immunochemistry staining $(66,70)$. In contrast, low detected rates have been reported using RT-PCR $(2.8 \% \sim 3.2 \%$ or undetectable) (71-73). The study performed in transgenic mouse has revealed that EGFRvIII mutant cancer cells are relatively resistant to EGFR-TKIs, but sensitive to irreversible EGFR inhibitor (71) and anti-EGFR antibody 806 (74).

\section{EGFR gene dosage}

Gene dosage is the number of copies of a gene present in a cell or nucleus. An increase in gene dosage means the gene is amplified. Gene amplification is a molecular mechanism responsible for oncogene overexpression. By production of multiple copies of a particular gene or genes, the phenotype that the gene confers is amplified in the cell. High copies of EGFR (amplification or high polysomy) have been detected in approximately $30 \%$ of NSCLC patients using fluo- 
rescence in situ hybridization (FISH), and it is usually associated with poor clinical prognosis (75). High copies of EGFR probably is an effective predictor for better treatment response to EGFR-TKIs (Table 2)(22, $23,76,77)$. Patients who have increased copies of EGFR gene show significant survival benefit from EGFR-TKIs treatment in both Phase II $(23,78)$ and Phase III clinical trials (Iressa Survival Evaluation in Lung cancer and BR.21) $(79,80)$ (Table 2).

High EGFR copy number is frequently correlated with EGFR somatic mutations $(22,27,31,81)$. This casts doubt about the independent predictive value. Additional preclinical and clinical studies with large sample size are paramount to resolving this issue. Since the mutation rate of EGFR is much lower among Caucasians $(\sim 10 \%)$ comparing with Asians (30 50\%) and a substantial portion of patients without EGFR mutations still benefit from EGFR-TKIs treatment, increased EGFR gene copy number could play its unique role in predicting EGFR-TKIs susceptibility. Japanese patients with EGFR gene amplification, however, do not benefit from gefitinib treatment (72).

Table 2 Detected EGFR copy number using FISH and EGFR-TKI treatment response in NSCLC

\begin{tabular}{|c|c|c|c|c|}
\hline Study subjects & \multicolumn{2}{|l|}{ Scoring criteria } & Result & Conclusion \\
\hline \multirow[t]{3}{*}{$\begin{array}{l}81 \\
\text { (Southwest Oncology } \\
\text { Group study 0126) }\end{array}$} & FISH negative & $\begin{array}{l}\text { with no or low genomic gain ( } \leq 4 \text { copies in } 40 \% \\
\text { cells) }\end{array}$ & $68 \%$ & $\begin{array}{l}\text { EGFR copy number is associ- } \\
\text { ated with improved survival } \\
\text { after gefitinib therapy (78) }\end{array}$ \\
\hline & \multirow{2}{*}{ FISH Positive } & high level of polysomy ( $\geq 4$ copies in $40 \%$ cells) & \multirow[b]{2}{*}{$32 \%$} & \\
\hline & & $\begin{array}{l}\text { Gene amplification } \\
\text { (EGFR/chr7 } \geq 2 \text {, or } \geq 15 \text { copies per cell in } \geq 10 \% \\
\text { cells) }\end{array}$ & & \\
\hline \multirow{6}{*}{102} & Disomy & $\leq 2$ copies in $>90 \%$ of cells & $35 \%$ & \multirow{6}{*}{$\begin{array}{l}\text { Gene amplification and high } \\
\text { polysomy has higher response } \\
\text { rate and better survival (23) }\end{array}$} \\
\hline & Low trisomy & $\begin{array}{l}\leq 2 \text { copies in } \geq 40 \% \text { of cells, } 3 \text { copies in } 10 \%-40 \% \text { of } \\
\text { the cells, } \geq 4 \text { copies in }<10 \% \text { of cells }\end{array}$ & $17 \%$ & \\
\hline & High trisomy & $\begin{array}{l}\leq 2 \text { copies in } \geq 40 \% \text { of cells, } 3 \text { copies in } \geq 40 \% \text { of cells, } \\
\geq 4 \text { copies in }<10 \% \text { of cells }\end{array}$ & $2 \%$ & \\
\hline & Low polysomy & $\geq 4$ copies in $10 \%-40 \%$ of cells & $14 \%$ & \\
\hline & High polysomy & $\geq 4$ copies in $\geq 40 \%$ of cells & $20.0 \%$ & \\
\hline & Gene amplification & EGFR/chr7 $\geq 2$, or $\geq 15$ copies per cell in $\geq 10 \%$ cells & $13 \%$ & \\
\hline \multirow{6}{*}{$\begin{array}{l}370 \\
\text { Phase III Iressa Survival } \\
\text { Evaluation in Lung Can- } \\
\text { cer }\end{array}$} & Disomy & $\leq 2$ copies in $>90 \%$ of cells & $69 \%$ & \multirow{6}{*}{$\begin{array}{l}\text { EGFR gene copy number is a } \\
\text { predictor for survival benefit } \\
\text { from gefitinib ( } 80) \text {. }\end{array}$} \\
\hline & Low trisomy & $\begin{array}{l}\leq 2 \text { copies in } \geq 40 \% \text { of cells, } 3 \text { copies in } 10 \%-40 \% \text { of } \\
\text { the cells, } \geq 4 \text { copies in }<10 \% \text { of cells }\end{array}$ & $16 \%$ & \\
\hline & High trisomy & $\begin{array}{l}\leq 2 \text { copies in } \geq 40 \% \text { of cells, } 3 \text { copies in } \geq 40 \% \text { of cells, } \\
\geq 4 \text { copies in }<10 \% \text { of cells }\end{array}$ & $24 \%$ & \\
\hline & Low polysomy & $\geq 4$ copies in $10 \%-40 \%$ of cells & $27 \%$ & \\
\hline & High polysomy & $\geq 4$ copies in $\geq 40 \%$ of cells & $17 \%$ & \\
\hline & Gene amplification & EGFR/chr7 $\geq 2$, or $\geq 15$ copies per cell in $\geq 10 \%$ cells & $14 \%$ & \\
\hline \multirow{6}{*}{$\begin{array}{l}125 \\
\text { Phase III clinical trial } \\
\text { BR.21 study }\end{array}$} & Disomy & $\leq 2$ copies in $>90 \%$ of cells & $10 \%$ & \multirow{6}{*}{$\begin{array}{l}\text { High copies of EGFR was } \\
\text { associated with survival bene- } \\
\text { fit from Erlotinib (79). }\end{array}$} \\
\hline & Low trisomy & $\begin{array}{l}\leq 2 \text { copies in } \geq 40 \% \text { of cells, } 3 \text { copies in } 10 \%-40 \% \text { of } \\
\text { the cells, } \geq 4 \text { copies in }<10 \% \text { of cells }\end{array}$ & $18 \%$ & \\
\hline & High trisomy & $\begin{array}{l}\leq 2 \text { copies in } \geq 40 \% \text { of cells, } 3 \text { copies in } \geq 40 \% \text { of cells, } \\
\geq 4 \text { copies in }<10 \% \text { of cells }\end{array}$ & $2 \%$ & \\
\hline & Low polysomy & $\geq 4$ copies in $10 \%-39 \%$ of cells & $24 \%$ & \\
\hline & High polysomy & $\geq 4$ copies in $\geq 40 \%$ of cells & $34 \%$ & \\
\hline & Gene amplification & EGFR/chr7 $\geq 2$, or $\geq 15$ copies per cell in $\geq 10 \%$ cells & $11 \%$ & \\
\hline \multirow{2}{*}{$\begin{array}{l}183 \\
\text { Pooled study subjects } \\
\text { from Italy and SWOG } \\
\text { study } 0126\end{array}$} & FISH negative & no or low genomic gain ( $\leq 4$ copies in $40 \%$ cells) & $68 \%$ & \multirow{2}{*}{$\begin{array}{l}\text { EGFR gene copy number is an } \\
\text { independent predictive bio- } \\
\text { marker for survival (77) }\end{array}$} \\
\hline & FISH Positive & $\begin{array}{l}\text { Gene amplification } \\
\text { (EGFR/chr } 7 \geq 2 \text {, or } \geq 15 \text { copies per cell in } \geq 10 \% \\
\text { cells) }\end{array}$ & $32 \%$ & \\
\hline
\end{tabular}

Table 3 EGFR protein expression and EGFR-TKI treatment response

\begin{tabular}{|c|c|c|c|c|}
\hline Sample size & Scoring criteria & & Results & Conclusion \\
\hline \multirow[t]{2}{*}{$\begin{array}{l}325 \text { (Phase III clinical trial } \\
\text { BR.21 study) }\end{array}$} & Negative & $\begin{array}{l}<10 \% \text { cells positive for membranous stain- } \\
\text { ing }\end{array}$ & $43 \%$ & \multirow{2}{*}{$\begin{array}{l}\text { EGFR expression is associated } \\
\text { with erlotinib treatment re- } \\
\text { sponse(79) }\end{array}$} \\
\hline & Positive & $\begin{array}{l}\geq 10 \% \text { of tumor cells positive for membra- } \\
\text { nous staining }\end{array}$ & $57 \%$ & \\
\hline \multirow[t]{4}{*}{100} & Negative & $0 \sim 99$ & \multirow[t]{2}{*}{$40 \%$} & \multirow{4}{*}{$\begin{array}{l}\text { EGFR protein status is associ- } \\
\text { ated with gefitinib treatment } \\
\text { response }(23)\end{array}$} \\
\hline & & $100 \sim 199$ & & \\
\hline & Positive & $200 \sim 299$ & $58 \%$ & \\
\hline & & $300 \sim 400$ & & \\
\hline \multirow{4}{*}{$\begin{array}{l}200 \text { (Pooled study subjects } \\
\text { from Italy and SWOG } \\
\text { study 0126) }\end{array}$} & Negative & $0 \sim 99$ & $39 \%$ & \multirow{4}{*}{$\begin{array}{l}\text { EGFR protein status is associ- } \\
\text { ated with treatment response } \\
\text { (77) }\end{array}$} \\
\hline & & 100 199 & & \\
\hline & Positive & $200 \sim 299$ & \multirow[t]{2}{*}{$61 \%$} & \\
\hline & & $300 \sim 400$ & & \\
\hline
\end{tabular}




\begin{tabular}{|c|c|c|c|c|}
\hline \multirow{4}{*}{$\begin{array}{l}379 \text { (Phase III Iressa Sur- } \\
\text { vival Evaluation in Lung } \\
\text { Cancer) }\end{array}$} & \multirow[t]{2}{*}{ Negative } & $0 \sim 99$ & \multirow[t]{2}{*}{$30 \%$} & \multirow{4}{*}{$\begin{array}{l}\text { EGFR protein status is associ- } \\
\text { ated with treatment response } \\
(80)\end{array}$} \\
\hline & & $100 \sim 199$ & & \\
\hline & \multirow[t]{2}{*}{ Positive } & $200 \sim 299$ & \multirow[t]{2}{*}{$70 \%$} & \\
\hline & & $300 \sim 400$ & & \\
\hline \multirow[t]{2}{*}{50} & $0 / 1+$ & Negative to faint immunoreactive cells & $54 \%$ & \multirow{2}{*}{$\begin{array}{l}\text { EGFR protein is not a signifi- } \\
\text { cant predictive factor for re- } \\
\text { sponse to gefitinib (88) }\end{array}$} \\
\hline & $2+/ 3+$ & Medium to strong immunoreactive cells & $46 \%$ & \\
\hline
\end{tabular}

*Percentage of positive tumor cells per slides $\times$ dominant intensity pattern of staining

\section{EGFR protein expression}

Overexpression of EGFR protein is very common in NSCLC patients $(40-80 \%)(13,14)$, and it is associated with aggressive clinical behaviors and poor prognosis (82-87). The relationship between EGFR protein level and EGFR-TKIs sensitivity has been studied intensively. Both positive $(23,77,79,80)$ and negative correlation $(88,89)$ have been reported (Table 3 ). The conflict observations partially could be attributed to the methodology (immunohistochemistry staining, IHC) applied for EGFR protein quantification because different laboratories use different antibodies, different scoring systems, and different protocols. EGFR protein is often associated with EGFR gene copy number $(23,75,90,91)$. Hirsch et al have recently suggested that patients with FISH and IHC double positive (approximately 23\%) probably can benefit more from EGFR-TKIs (77).

\section{HER 2 expression and gene dosage}

HER2 is another member of erbB transmembrane receptor family. It has intrinsic kinase activity. HER2 is known to be a preferred coreceptor for EGFR in the process of EGFR heterodimerization. Increased expression of HER2 is associated with inferior survival in NSCLC patients, and high EGFR and HER2 coexpression has additive impact on unfavorable prognosis (92). Overexpression of HER2 protein is not associated with gefitinib response and survival $(76,93)$. Neither is HER2 copy number (78). However, HER2 amplification could predict gefitinib sensitivity and survival among NSCLC patients with increased EGFR copy number $(76,94)$.

\section{Akt phosphorylation}

The phosphatidylinositol 3'-kinases (PI3K)/Akt pathway is one of the important downstream signal transduction pathways of EGFR. It plays critical role in regulating cell survival and apoptosis. Akt activation is able to protects cells from apoptosis by inactivating pro apoptotic proteins $(95,96)$. Increased PI3K/Akt activity has been observed in NSCLC. Positive p-Akt expression is associated with better gefitinib responsiveness and prognosis $(77,97,98)$. Conflicting result have also indicated that p-Akt is not associated with EGFR-TKI efficacy (99).

\section{Gene expression signature and mass spectrometry}

Gene expression signature and mass spectrometry are fast growing area in cancer research. Although both biotechnologies are costly, they are robust for new biomarkers discovery. For patients who are negative for EGFR mutations and/or other markers, gene expression and mass spectrometry analysis probably could introduce new insight into clinical practice to assure better clinical outcomes. By comparing the gene expression patterns of gefitinib sensitive and gefitinib resistant lung cancer, Balko and Coldren et al have found several novel markers associated with gefitinib sensitivity $(100,101)$. In addition, they have generated a multivariate model, which is supposed to provide more accurate prediction for EGFR-TKI sensitivity than single biomarkers or clinical characteristics (100).

Mass spectrometry is currently the most powerful analytic proteomic tool. Using mass spectrometry Taguchi et al have performed a multicohort cross-institutional study to investigate serum predictive biomarkers for clinical outcome after EGFR-TKIs treatment. They have identified eight distinct peaks and developed an algorithm, which could be used for patients selection and to predict prognosis after EGFR-TKI treatment (102). However, there are some concerns regarding the predictive value because the identities of the eight discriminatory peaks remain unknown and there are no other validation tests performed beyond their laboratory.

\section{Discussion}

Identifying a panel of predictive markers is important for selection of advanced NSCLC patients for EGFR-TKI therapy. Although several important demographic and clinical factors are associated with treatment response, EGFR somatic mutations are still the most effective predictor for EGFR-TKI sensitivity. EGFR mutation screening could be number one test to provide the most direct and valuable information to help clinicians to make treatment decision. Among NSCLC patients with EGFR-TKI susceptible mutations $70 \%$ of objective response rate or higher can be expected with progression-free survival of at least 7.7 months upon gefitinib/erlotinib treatment. Moreover, mutation analysis can also provide insight into resistance mechanisms to EGFR-TKIs by NSCLC cells. 
The question, however, is who should have EGFR mutation screening test. We recommend all advanced NSCLC patients to consider mutation test before EGFR-TKIs treatment. For female patients with favorable clinical factors such as adenocarcinoma and/or low exposure to smoking, mutation test might not be necessary if the patients object to the test or the test is not available. Male patients with squamous-cell carcinoma or heavy smoking history and failing standard chemotherapy had little possibility responding to EGFR-TKI. It is prudent to test EGFR mutation before starting EGFR-TKI treatment.

Regarding the specimen and the method used for mutation analysis, we do not think the answer is universal, and the choices are multiple. By now direct sequencing is the most commonly used method for EGFR mutation screening although the sensitivity is often concerned, especially for heterogeneous specimens, such as pleural effusion drainage, blood or plasma. In addition, a number of genotyping methods with high sensitivity have been developed for EGFR mutation screening, such as single-strand conformation polymorphism (SSCP), scorpion allele specific PCR, mutation enriched PCR, and peptide nucleic acid-locked nucleic acid (PNA-LNA) PCR clamp. Most of them are able to detect even one EGFR mutant tumor cell with the presence of up to 1000-2000 normal cells(103-106). However, these sensitive methods have only been tested in small number of patients, and they are available in limited numbers of research laboratories. These methods are also needed to be standardized and validated. Therefore, under current situation direct sequencing probably is a mature method which could be used in health institutions for routine clinical mutation screening. For the commonly known mutations, such as deletion in exon 19, L858R, and T790M, gene scan, Scorpion allele specific PCR, and TaqMan genotyping assay are applicable. These methods are highly sensitive and easy to handle.

Among EGFR mutation negative patients, other predictive markers, such as EGFR copy number detected by FISH or K-ras mutation could provide important information in deciding the use of EGFR-TKIs for NSCLC patients.

\section{Conclusions}

EGFR mutation is the most effective molecular predictor of sensitivity in patients with advanced NSCLC to EGFR-TKIs treatment. Almost $75 \%$ of patient with EGFR mutations will have objective response to either gefitinib or erlotinib. Other molecular markers or methods, such as EGFR gene copy numbers, K-ras mutation, gene expression signature or serum protein profiles by mass spectroscopy may add additional value but require further studies.

\section{Conflict of Interest}

The authors have declared that no conflict of interest exists.

\section{References}

1. Parkin DM. Global cancer statistics in the year 2000. Lancet Oncol. 2001; 2(9): 533-43.

2. Brambilla E, Travis WD, Colby TV, et al. The new World Health Organization classification of lung tumours. Eur Respir J. 2001; 18(6): 1059-68.

3. Travis WD, Travis LB, Devesa SS. Lung cancer. Cancer. 1995; 75(1 Suppl): 191-202.

4. Franceschi S, Bidoli E. The epidemiology of lung cancer. Ann Oncol. 1999; 10 (Suppl 5): S3-6.

5. Miller JD, Gorenstein LA, Patterson GA. Staging: the key to rational management of lung cancer. Ann Thorac Surg. 1992; 53(1): 170-8.

6. Fossella FV, DeVore R, Kerr RN, et al. Randomized phase III trial of docetaxel versus vinorelbine or ifosfamide in patients with advanced non-small-cell lung cancer previously treated with platinum-containing chemotherapy regimens. The TAX 320 Non-Small Cell Lung Cancer Study Group. J Clin Oncol. 2000; 18(12): 2354-62.

7. Marino P, Pampallona S, Preatoni A, et al. Chemotherapy vs supportive care in advanced non-small-cell lung cancer. Results of a meta-analysis of the literature. Chest. 1994; 106(3): 861-5.

8. Grilli R, Oxman AD, Julian JA. Chemotherapy for advanced non-small-cell lung cancer: how much benefit is enough? J Clin Oncol. 1993; 11(10): 1866-72.

9. Schlessinger J. Cell signaling by receptor tyrosine kinases. Cell. 2000; 103(2): 211-25.

10. Yarden Y, Sliwkowski MX. Untangling the ErbB signalling network. Nat Rev Mol Cell Biol. 2001; 2(2): 127-37.

11. Scagliotti GV, Selvaggi G, Novello S, et al. The biology of epidermal growth factor receptor in lung cancer. Clin Cancer Res. 2004; 10(12 Pt 2): 4227s-32s.

12. Mendelsohn J, Baselga J. The EGF receptor family as targets for cancer therapy. Oncogene. 2000; 19(56): 6550-65.

13. Salomon DS, Brandt R, Ciardiello F, et al. Epidermal growth factor-related peptides and their receptors in human malignancies. Crit Rev Oncol Hematol. 1995; 19(3): 183-232.

14. Ennis BW, Lippman ME, Dickson RB. The EGF receptor system as a target for antitumor therapy. Cancer Invest. 1991; 9(5): 553-62.

15. Shepherd FA, Rodrigues Pereira J, Ciuleanu T, et al. Erlotinib in previously treated non-small-cell lung cancer. N Engl J Med. 2005; 353(2): 123-32.

16. Chang A, Parikh P, Thongprasert S, et al. Gefitinib (IRESSA) in patients of Asian origin with refractory advanced non-small cell lung cancer: subset analysis from the ISEL study. J Thorac Oncol. 2006; 1(8): 847-55.

17. Fukuoka M, Yano S, Giaccone G, et al. Multi-institutional randomized phase II trial of gefitinib for previously treated patients with advanced non-small-cell lung cancer (The IDEAL 1 Trial) [corrected]. J Clin Oncol. 2003; 21(12): 2237-46.

18. Kris MG, Natale RB, Herbst RS, et al. Efficacy of gefitinib, an inhibitor of the epidermal growth factor receptor tyrosine kinase, in symptomatic patients with non-small cell lung cancer: a randomized trial. Jama. 2003; 290(16): 2149-58.

19. Miller VA, Kris MG, Shah N, et al. Bronchioloalveolar pathologic subtype and smoking history predict sensitivity to gefitinib in 
advanced non-small-cell lung cancer. J Clin Oncol. 2004; 22(6): 1103-9.

20. Lynch TJ, Bell DW, Sordella R, et al. Activating mutations in the epidermal growth factor receptor underlying responsiveness of non-small-cell lung cancer to gefitinib. N Engl J Med. 2004; 350(21): 2129-39.

21. Paez JG, Janne PA, Lee JC, et al. EGFR mutations in lung cancer: correlation with clinical response to gefitinib therapy. Science. 2004; 304(5676): 1497-500.

22. mTakano T, Ohe $\mathrm{Y}$, Sakamoto $\mathrm{H}$, et al. Epidermal growth factor receptor gene mutations and increased copy numbers predict gefitinib sensitivity in patients with recurrent non-small-cell lung cancer. J Clin Oncol. 2005; 23(28): 6829-37.

23. Cappuzzo F, Hirsch FR, Rossi E, et al. Epidermal growth factor receptor gene and protein and gefitinib sensitivity in non-small-cell lung cancer. J Natl Cancer Inst. 2005; 97(9): 643-55.

24. Huang SF, Liu HP, Li LH, et al. High frequency of epidermal growth factor receptor mutations with complex patterns in non-small cell lung cancers related to gefitinib responsiveness in Taiwan. Clin Cancer Res. 2004; 10(24): 8195-203.

25. Eberhard DA, Johnson BE, Amler LC, et al. Mutations in the epidermal growth factor receptor and in KRAS are predictive and prognostic indicators in patients with non-small-cell lung cancer treated with chemotherapy alone and in combination with erlotinib. J Clin Oncol. 2005; 23(25): 5900-9.

26. Mitsudomi T, Kosaka T, Endoh H, et al. Mutations of the epidermal growth factor receptor gene predict prolonged survival after gefitinib treatment in patients with non-small-cell lung cancer with postoperative recurrence. J Clin Oncol. 2005; 23(11): 2513-20.

27. Taron M, Ichinose $Y$, Rosell R, et al. Activating mutations in the tyrosine kinase domain of the epidermal growth factor receptor are associated with improved survival in gefitinib-treated chemorefractory lung adenocarcinomas. Clin Cancer Res. 2005; 11(16): 5878-85.

28. Shih JY, Gow CH, Yu CJ, et al. Epidermal growth factor receptor mutations in needle biopsy/aspiration samples predict response to gefitinib therapy and survival of patients with advanced nonsmall cell lung cancer. Int J Cancer. 2006; 118(4): 963-9.

29. Marx J. Medicine. Why a new cancer drug works well, in some patients. Science. 2004; 304(5671): 658-9.

30. Sordella R, Bell DW, Haber DA, et al. Gefitinib-sensitizing EGFR mutations in lung cancer activate anti-apoptotic pathways. Science. 2004; 305(5687): 1163-7.

31. Tracy S, Mukohara T, Hansen M, et al. Gefitinib induces apoptosis in the EGFRL858R non-small-cell lung cancer cell line H3255. Cancer Res. 2004; 64(20): 7241-4.

32. Sunaga N, Tomizawa Y, Yanagitani N, et al. Phase II prospective study of the efficacy of gefitinib for the treatment of stage III/IV non-small cell lung cancer with EGFR mutations, irrespective of previous chemotherapy. Lung Cancer. 2007; 56(3): 383-9.

33. Asahina H, Yamazaki K, Kinoshita I, et al. A phase II trial of gefitinib as first-line therapy for advanced non-small cell lung cancer with epidermal growth factor receptor mutations. Br J Cancer. 2006; 95(8): 998-1004.

34. Inoue A, Suzuki T, Fukuhara T, et al. Prospective phase II study of gefitinib for chemotherapy-naive patients with advanced non-small-cell lung cancer with epidermal growth factor receptor gene mutations. J Clin Oncol. 2006; 24(21): 3340-6.

35. Yoshida K, Yatabe Y, Park JY, et al. Prospective validation for prediction of gefitinib sensitivity by epidermal growth factor receptor gene mutation in patients with non-small cell lung cancer. J Thorac Oncol. 2007; 2(1): 22-8.

36. Paz-Ares L, Sanchez J, Garcia-Velasco A, et al. A prospective phase II trial of erlotinib in advanced non-small cell lung cancer (NSCLC) patients (p) with mutations in the tyrosine kinase (TK) domain of the epidermal growth factor receptor (EGFR). 2006 ASCO annual Meeting. 2006.

37. van Zandwijk N, Mathy A, Boerrigter L, et al. EGFR and KRAS mutations as criteria for treatment with tyrosine kinase inhibitors: retro- and prospective observations in non-small-cell lung cancer. Ann Oncol. 2007; 18(1): 99-103.

38. Sequist LV, Martins RG, Spigel D, et al. First-Line Gefitinib in Patients With Advanced Non-Small-Cell Lung Cancer Harboring Somatic EGFR Mutations. J Clin Oncol. 2008; 26(15): 2442-9.

39. Jackman DM, Yeap BY, Sequist LV, et al. Exon 19 deletion mutations of epidermal growth factor receptor are associated with prolonged survival in non-small cell lung cancer patients treated with gefitinib or erlotinib. Clin Cancer Res. 2006; 12(13): 3908-14.

40. Zhang $X$, Chang A. Somatic mutations of the epidermal growth factor receptor and non-small-cell lung cancer. J Med Genet. 2007; 44(3): 166-72.

41. Riely GJ, Pao W, Pham D, et al. Clinical course of patients with non-small cell lung cancer and epidermal growth factor receptor exon 19 and exon 21 mutations treated with gefitinib or erlotinib. Clin Cancer Res. 2006; 12(3 Pt 1): 839-44.

42. Pao W, Miller VA, Politi KA, et al. Acquired resistance of lung adenocarcinomas to gefitinib or erlotinib is associated with a second mutation in the EGFR kinase domain. PLoS Med. 2005; 2(3): e73.

43. Kobayashi S, Boggon TJ, Dayaram T, et al. EGFR mutation and resistance of non-small-cell lung cancer to gefitinib. N Engl J Med. 2005; 352(8): 786-92.

44. Balak MN, Gong Y, Riely GJ, et al. Novel D761Y and common secondary T790M mutations in epidermal growth factor receptor-mutant lung adenocarcinomas with acquired resistance to kinase inhibitors. Clin Cancer Res. 2006; 12(21): 6494-501.

45. Costa DB, Halmos B, Kumar A, et al. BIM mediates EGFR tyrosine kinase inhibitor-induced apoptosis in lung cancers with oncogenic EGFR mutations. PLoS Med. 2007; 4(10): 1669-79.

46. Sasaki H, Endo K, Takada M, et al. EGFR exon 20 insertion mutation in Japanese lung cancer. Lung Cancer. 2007; 58(3): 324-8.

47. Greulich H, Chen TH, Feng W, et al. Oncogenic transformation by inhibitor-sensitive and -resistant EGFR mutants. PLoS Med. 2005; 2(11): e313.

48. Yun $\mathrm{CH}$, Mengwasser KE, Toms AV, et al. The T790M mutation in EGFR kinase causes drug resistance by increasing the affinity for ATP. Proc Natl Acad Sci U S A. 2008; 105(6): 2070-5.

49. Birchmeier C, Birchmeier W, Gherardi E, et al. Met, metastasis, motility and more. Nat Rev Mol Cell Biol. 2003; 4(12): 915-25.

50. Smolen GA, Sordella R, Muir B, et al. Amplification of MET may identify a subset of cancers with extreme sensitivity to the selective tyrosine kinase inhibitor PHA-665752. Proc Natl Acad Sci U S A. 2006; 103(7): 2316-21.

51. Miller CT, Lin L, Casper AM, et al. Genomic amplification of MET with boundaries within fragile site FRA7G and upregulation of MET pathways in esophageal adenocarcinoma. Oncogene. 2006; 25(3): 409-18.

52. Jeffers M, Schmidt L, Nakaigawa N, et al. Activating mutations for the met tyrosine kinase receptor in human cancer. Proc Natl Acad Sci U S A. 1997; 94(21): 11445-50.

53. Bean J, Brennan C, Shih JY, et al. MET amplification occurs with or without T790M mutations in EGFR mutant lung tumors with acquired resistance to gefitinib or erlotinib. Proc Natl Acad Sci U S A. 2007; 104(52): 20932-7.

54. Engelman JA, Zejnullahu K, Mitsudomi T, et al. MET amplification leads to gefitinib resistance in lung cancer by activating ERBB3 signaling. Science. 2007; 316(5827): 1039-43.

55. Bos JL. ras oncogenes in human cancer: a review. Cancer Res. 1989; 49(17): 4682-9.

56. Keohavong P, DeMichele MA, Melacrinos AC, et al. Detection of K-ras mutations in lung carcinomas: relationship to prognosis. Clin Cancer Res. 1996; 2(2): 411-8. 
57. Rodenhuis S, van de Wetering ML, Mooi WJ, et al. Mutational activation of the K-ras oncogene. A possible pathogenetic factor in adenocarcinoma of the lung. N Engl J Med. 1987; 317(15): 929-35.

58. Rodenhuis S, Slebos RJ, Boot AJ, et al. Incidence and possible clinical significance of K-ras oncogene activation in adenocarcinoma of the human lung. Cancer Res. 1988; 48(20): 5738-41.

59. Fukuyama Y, Mitsudomi T, Sugio K, et al. K-ras and p53 mutations are an independent unfavourable prognostic indicator in patients with non-small-cell lung cancer. Br J Cancer. 1997; 75(8): 1125-30.

60. Cho JY, Kim JH, Lee YH, et al. Correlation between K-ras gene mutation and prognosis of patients with nonsmall cell lung carcinoma. Cancer. 1997; 79(3): 462-7.

61. Kosaka T, Yatabe Y, Endoh H, et al. Mutations of the epidermal growth factor receptor gene in lung cancer: biological and clinical implications. Cancer Res. 2004; 64(24): 8919-23.

62. Shigematsu H, Lin L, Takahashi T, et al. Clinical and biological features associated with epidermal growth factor receptor gene mutations in lung cancers. J Natl Cancer Inst. 2005; 97(5): 339-46.

63. Marchetti A, Martella C, Felicioni L, et al. EGFR mutations in non-small-cell lung cancer: analysis of a large series of cases and development of a rapid and sensitive method for diagnostic screening with potential implications on pharmacologic treatment. J Clin Oncol. 2005; 23(4): 857-65.

64. Pao W, Wang TY, Riely GJ, et al. KRAS mutations and primary resistance of lung adenocarcinomas to gefitinib or erlotinib. PLoS Med. 2005; 2(1): e17.

65. Schwechheimer K, Huang S, Cavenee WK. EGFR gene amplification--rearrangement in human glioblastomas. Int J Cancer. 1995; 62(2): 145-8.

66. Garcia de Palazzo IE, Adams GP, Sundareshan P, et al. Expression of mutated epidermal growth factor receptor by non-small cell lung carcinomas. Cancer Res. 1993; 53(14): 3217-20.

67. Downward J, Yarden Y, Mayes E, et al. Close similarity of epidermal growth factor receptor and v-erb-B oncogene protein sequences. Nature. 1984; 307(5951): 521-7.

68. Wikstrand CJ, Hale LP, Batra SK, et al. Monoclonal antibodies against EGFRvIII are tumor specific and react with breast and lung carcinomas and malignant gliomas. Cancer Res. 1995; 55(14): 3140-8.

69. Moscatello DK, Holgado-Madruga M, Godwin AK, et al. Frequent expression of a mutant epidermal growth factor receptor in multiple human tumors. Cancer Res. 1995; 55(23): 5536-9.

70. Okamoto I, Kenyon LC, Emlet DR, et al. Expression of constitutively activated EGFRvIII in non-small cell lung cancer. Cancer Sci. 2003; 94(1): 50-6.

71. Ji H, Zhao X, Yuza Y, et al. Epidermal growth factor receptor variant III mutations in lung tumorigenesis and sensitivity to tyrosine kinase inhibitors. Proc Natl Acad Sci U S A. 2006; 103(20): 7817-22.

72. Sasaki H, Endo K, Okuda K, et al. Epidermal growth factor receptor gene amplification and gefitinib sensitivity in patients with recurrent lung cancer. J Cancer Res Clin Oncol. 2008;134(5):569-77..

73. Ohtsuka K, Ohnishi H, Furuyashiki G, et al. Clinico-pathological and biological significance of tyrosine kinase domain gene mutations and overexpression of epidermal growth factor receptor for lung adenocarcinoma. J Thorac Oncol. 2006; 1(8): 787-95.

74. Li D, Ji H, Zaghlul S, et al. Therapeutic anti-EGFR antibody 806 generates responses in murine de novo EGFR mutant-dependent lung carcinomas. J Clin Invest. 2007; 117(2): 346-52.

75. Hirsch FR, Varella-Garcia M, Bunn PA Jr, et al. Epidermal growth factor receptor in non-small-cell lung carcinomas: correlation between gene copy number and protein expression and impact on prognosis. J Clin Oncol. 2003; 21(20): 3798-807.
76. Cappuzzo F, Varella-Garcia M, Shigematsu H, et al. Increased HER2 gene copy number is associated with response to gefitinib therapy in epidermal growth factor receptor-positive non-small-cell lung cancer patients. J Clin Oncol. 2005; 23(22): 5007-18.

77. Hirsch FR, Varella-Garcia M, Cappuzzo F, et al. Combination of EGFR gene copy number and protein expression predicts outcome for advanced non-small-cell lung cancer patients treated with gefitinib. Ann Oncol. 2007; 18(4): 752-60.

78. Hirsch FR, Varella-Garcia M, McCoy J, et al. Increased epidermal growth factor receptor gene copy number detected by fluorescence in situ hybridization associates with increased sensitivity to gefitinib in patients with bronchioloalveolar carcinoma subtypes: a Southwest Oncology Group Study. J Clin Oncol. 2005; 23(28): 6838-45.

79. Tsao MS, Sakurada A, Cutz JC, et al. Erlotinib in lung cancer molecular and clinical predictors of outcome. $\mathrm{N}$ Engl J Med. 2005; 353(2): 133-44.

80. Hirsch FR, Varella-Garcia M, Bunn PA Jr, et al. Molecular predictors of outcome with gefitinib in a phase III placebo-controlled study in advanced non-small-cell lung cancer. J Clin Oncol. 2006; 24(31): 5034-42.

81. Amann J, Kalyankrishna S, Massion PP, et al. Aberrant epidermal growth factor receptor signaling and enhanced sensitivity to EGFR inhibitors in lung cancer. Cancer Res. 2005; 65(1): 226-35.

82. Pavelic K, Banjac Z, Pavelic J, et al. Evidence for a role of EGF receptor in the progression of human lung carcinoma. Anticancer Res. 1993; 13(4): 1133-7.

83. Ohsaki Y, Tanno S, Fujita Y, et al. Epidermal growth factor receptor expression correlates with poor prognosis in non-small cell lung cancer patients with p53 overexpression. Oncol Rep. 2000; 7(3): 603-7.

84. Volm M, Rittgen W, Drings P. Prognostic value of ERBB-1, VEGF, cyclin A, FOS, JUN and MYC in patients with squamous cell lung carcinomas. Br J Cancer. 1998; 77(4): 663-9.

85. Nicholson RI, Gee JM, Harper ME. EGFR and cancer prognosis. Eur J Cancer. 2001; 37 (Suppl 4): S9-15.

86. Veale D, Kerr N, Gibson GJ, et al. The relationship of quantitative epidermal growth factor receptor expression in non-small cell lung cancer to long term survival. Br J Cancer. 1993; 68(1): $162-5$.

87. Meert AP, Martin B, Delmotte P, et al. The role of EGF-R expression on patient survival in lung cancer: a systematic review with meta-analysis. Eur Respir J. 2002; 20(4): 975-81.

88. Parra HS, Cavina R, Latteri F, et al. Analysis of epidermal growth factor receptor expression as a predictive factor for response to gefitinib ('Iressa', ZD1839) in non-small-cell lung cancer. Br J Cancer. 2004; 91(2): 208-12.

89. Bailey R, Kris M, Wolf M. Gefitinib (Iressa, ZD 1839) monotherapy for pretreated advanced non-small cell lung cancer in IDEAL 1 and 2: tumor response is not clinically relevantly predictable from tumor EGFR membrane staining alone. Lung Cancer. 2003; 41(S71): 242.

90. Jeon YK, Sung SW, Chung JH, et al. Clinicopathologic features and prognostic implications of epidermal growth factor receptor (EGFR) gene copy number and protein expression in non-small cell lung cancer. Lung Cancer. 2006; 54(3): 387-98.

91. Dziadziuszko R, Holm B, Skov BG, et al. Epidermal growth factor receptor gene copy number and protein level are not associated with outcome of non-small-cell lung cancer patients treated with chemotherapy. Ann Oncol. 2007; 18(3): 447-52.

92. Brabender J, Danenberg KD, Metzger R, et al. Epidermal growth factor receptor and HER2-neu mRNA expression in non-small cell lung cancer Is correlated with survival. Clin Cancer Res. 2001; 7(7): 1850-5.

93. Cappuzzo F, Gregorc V, Rossi E, et al. Gefitinib in pretreated non-small-cell lung cancer (NSCLC): analysis of efficacy and 
correlation with HER2 and epidermal growth factor receptor expression in locally advanced or metastatic NSCLC. J Clin Oncol. 2003; 21(14): 2658-63.

94. Daniele L, Macri L, Schena M, et al. Predicting gefitinib responsiveness in lung cancer by fluorescence in situ hybridization/chromogenic in situ hybridization analysis of EGFR and HER2 in biopsy and cytology specimens. Mol Cancer Ther. 2007; 6(4): 1223-9.

95. Datta SR, Dudek H, Tao X, et al. Akt phosphorylation of BAD couples survival signals to the cell-intrinsic death machinery. Cell. 1997; 91(2): 231-41.

96. Cardone MH, Roy N, Stennicke HR, et al. Regulation of cell death protease caspase-9 by phosphorylation. Science. 1998; 282(5392): 1318-21.

97. Han SW, Hwang PG, Chung DH, et al. Epidermal growth factor receptor (EGFR) downstream molecules as response predictive markers for gefitinib (Iressa, ZD1839) in chemotherapy-resistant non-small cell lung cancer. Int J Cancer. 2005; 113(1): 109-15.

98. Cappuzzo F, Magrini E, Ceresoli GL, et al. Akt phosphorylation and gefitinib efficacy in patients with advanced non-small-cell lung cancer. J Natl Cancer Inst. 2004; 96(15): 1133-41.

99. Cappuzzo F, Ligorio C, Toschi L, et al. EGFR and HER2 gene copy number and response to first-line chemotherapy in patients with advanced non-small cell lung cancer (NSCLC). J Thorac Oncol. 2007; 2(5): 423-9.

100.Balko JM, Potti A, Saunders C, et al. Gene expression patterns that predict sensitivity to epidermal growth factor receptor tyrosine kinase inhibitors in lung cancer cell lines and human lung tumors. BMC Genomics. 2006; 7: 289.

101.Coldren CD, Helfrich BA, Witta SE, et al. Baseline gene expression predicts sensitivity to gefitinib in non-small cell lung cancer cell lines. Mol Cancer Res. 2006; 4(8): 521-8.

102.Taguchi F, Solomon B, Gregorc V, et al. Mass spectrometry to classify non-small-cell lung cancer patients for clinical outcome after treatment with epidermal growth factor receptor tyrosine kinase inhibitors: a multicohort cross-institutional study. J Natl Cancer Inst. 2007; 99(11): 838-46.

103.Nagai Y, Miyazawa H, et al. Genetic heterogeneity of the epidermal growth factor receptor in non-small cell lung cancer cell lines revealed by a rapid and sensitive detection system, the peptide nucleic acid-locked nucleic acid PCR clamp. Cancer Res. 2005; 65(16): 7276-82.

104.Sugio K, Uramoto H, Ono K, et al. Mutations within the tyrosine kinase domain of EGFR gene specifically occur in lung adenocarcinoma patients with a low exposure of tobacco smoking. Br J Cancer. 2006; 94(6): 896-903.

105.Asano H, Toyooka S, Tokumo M, et al. Detection of EGFR gene mutation in lung cancer by mutant-enriched polymerase chain reaction assay. Clin Cancer Res. 2006; 12(1): 43-8.

106.Zhang X, Zhao Y, Wang M, et al. Detection and comparison of epidermal growth factor receptor mutations in cells and fluid of malignant pleural effusion in non-small cell lung cancer. Lung Cancer. 2008;60(2):175-82. 